\title{
THE REPORTING OF NON-FINANCIAL INFORMATION AND THE RATIONALE FOR ITS STANDARDISATION
}

\author{
Peter Krištofík, Marzanna Lament, Hussam Musa
}

\section{Introduction}

CSR (Corporate Social Responsibility) is an important part of communication with stakeholders and a response to the need for non-financial reports. Regrettably the rules of non-financial reporting are not regulated - except by Directive 2014/95/EU, which will apply to large enterprises of public interest, and which must be introduced by the member states by 6 December 2016. CSR reports are drafted using a variety of principles and guidelines, which limits comparisons across enterprises, transparency and the assessment of progress made on the realisation of CSR goals.

Communication of an organisation's performance in its economic, social and environmental dimensions to the parties concerned is the principal function of the CSR reporting process. In this way, an enterprise demonstrates effectiveness of its actions in the area of social responsibility management. Thus, CSR reporting should be part of the process of creating an organisation's strategy, implementation of its action plans and evaluation of results, as well as a tool for improvement of a CSR management system, involving stakeholders and obtaining their contributions to functioning of an organisation (GRI Second G4 Public Comment).

CSR reporting is an integral part of the concept of corporate social responsibility, according to which business is an economic institution responsible for both providing social services and generation of profits (Berle, 1931; Dodd, 1932). The European Commission defines CSR as responsibility of enterprises for their impact on society (Green Paper, 2011). According to Caroll (1979), responsibility of enterprises encompasses four key areas: economic, legal, ethical and philanthropic, all of which should be integrated into strategic management. They allow an enterprise to reach an equilibrium of three dimensions of its activities: economic, social and environmental (Triple-Bottom-Line - Three P's Balance: Planet, Profit, People). ISO 26000 states integrating assumptions of the corporate social responsibility into a management system is an effective way of implementing the concept. According to Sopkova and Raškovska (2012), at present the concept of social responsibility is an important part of corporate strategies. Horehajova and Marasova (2008) have identified three main expressions of the CSR:

- hierarchical - represents the conception of the CSR with the leading role of managers,

- participative - represents a more balanced form of the CSR which is based not only on managers but also on employees or their representatives,

- minimalist - consists of compulsory CSR imposed by the state and voluntary CSR that appears as a limited commitment of a company.

The scope and quality of information and reporting disclosures play an important part in building socio-economic relations of an enterprise and its environment and are addressed by systemic theories, referred to as open system theories (Deegan \& Unerman, 2011). They help to explain causes of extended information disclosures by enterprises that go beyond financial reports to additionally include environmental and social issues. The concept of corporate social responsibility is based on the theory of stakeholders, which assumes an enterprise is linked to a variety of groups that affect its activities and in turn are under its impact (Freeman, 1984). In the classic version, this objective was referred to maximisation of total benefits, mainly to shareholders, from capitals committed to an enterprise. At present, it is seen in a broader perspective and applied to other stakeholder groups as well, which means value optimisation for stakeholders, i.e. 
achievement of sustainable value, becomes the enterprise's objective - benefits to shareholders do not detract from benefits accruing to other stakeholders. Due to varying scopes of benefits to stakeholders, their differing perception and extents of knowledge, it appears reasonable to enhance information openness of enterprises, that is, to standardise principles of reporting, which would be bound to help limit the information asymmetry between diverse groups of stakeholders.

Therefore, the subject appears topical and requires a solution by indicating principles of reporting prevailing with socially responsible entities and by verifying reasons for which enterprises select certain reporting standards.

The aims of this paper are to examine the reasons for reporting non-financial information cited in the specialist literature and by enterprises preparing CSR reports, and to determine the benefits of standardising reports on non-financial information.

The following hypotheses are tested:

1. Communication with stakeholders is the fundamental reason for compiling reports on non-financial information (H1). This will be verified by analysing the literature, and the results of a survey of enterprises implementing CSR ideas.

2. The need to standardise CSR reporting, to ensure its transparency and clarity, is noted by reporting organisations $(\mathrm{H} 2)$. This will be verified by analysing the principles of reporting by socially responsible entities in 2010-2014, by regions of the world and by company size, evaluated jointly or separately.

The rest of the paper is organised as follows. Section 1 reviews the recent theoretical and empirical literature on CSR reporting and outlines some of its general themes. Section 2 presents the surveyed reasons for CSR reporting in enterprises. Section 3 contains the arguments for standardization of non-financial information. Section 4 examines trends in CSR reporting, evaluates extent of its standardization and concludes.

\section{Benefits of Corporate Social Responsibility (CSR) Reporting - Review of the Literature}

CSR reporting, part of CSR strategy, provides for the evaluation and monitoring of progress made on objectives and supports the implementation of action strategies via the commitment of employees and other stakeholders. Thus, it assures effective action, raises awareness of CSR issues and improves the image of an enterprise. It is above all an opportunity for the presentation of an enterprise and for communication with stakeholders.

These arguments are the chief causes of CSR reporting and the subjects of research. Emphasis on the benefits of CSR reporting prevails in the relevant literature. Some claim, however, that CSR reporting is unnecessary and fails to positively affect business and the image of enterprises (Maignam, 2001; Jones, Pelsmacker, Driesen, \& Rayp, 2005; Comfort $\&$ Hillier, 2006). The literature on the causes and benefits of CSR reporting distinguishes the following reasons for reporting:

- meet requirements of stakeholders - a form of communication with stakeholders,

- improve image and reputation of enterprises,

- enhance brand value,

- be a major element of strategic management that helps achieve objectives and realise corporate strategy,

- increase profits and minimise risk,

- provide for comparative analysis of CSR.

According to Juscius, Sneideriene and Griauslyte (2014), there are two main reasons that drive the growing scale of CSR reporting:

1. Stakeholder pressure for reporting on CSR activities:

$\square$ Government pressure,

$\square \quad$ NGO pressure,

$\square$ Recommendations of financial organizations, Investor pressure.

2. The benefits for business of reporting on CSR activities:

$\square$ Reduce the risk of sanctions,

$\square$ Increase productivity and profitability,

$\square$ Open up communication channels (reputation, recruitment of talented employees, consumer loyalty, public support, easier access to capital).

A detailed analysis of reasons for CSR reporting is tabulated below.

The review of the literature on the benefits of CSR reporting shows that the information requirements of stakeholders were primarily indicated as the main reason for the reporting, at the initial development stages of the process of disclosing non-financial information. In time, 


\section{Tab. 1: Reasons for CSR reporting identified in its research literature (Part 1)}

\begin{tabular}{|c|c|c|c|c|}
\hline No. & $\begin{array}{l}\text { Reasons for CSR } \\
\text { reporting }\end{array}$ & Author & Year & Benefits of CSR reporting \\
\hline \multirow[t]{10}{*}{1.} & \multirow{10}{*}{$\begin{array}{l}\text { Satisfy the needs } \\
\text { of stakeholders. } \\
\text { Form of } \\
\text { communication } \\
\text { with stakeholders. }\end{array}$} & $\begin{array}{l}\text { S.O. Idowu, B.A. } \\
\text { Towler }\end{array}$ & 2004 & $\begin{array}{l}\text { CSR reporting is the stakeholders' right to know } \\
\text { about the company's contribution to increasing } \\
\text { public welfare. }\end{array}$ \\
\hline & & $\begin{array}{l}\text { B.A. Towler, S.O. } \\
\text { Idowu }\end{array}$ & 2004 & $\begin{array}{l}80 \% \text { of the } 100 \text { largest UK companies whose } \\
\text { shares are quoted on the London Stock } \\
\text { Exchange prepare CSR reports. }\end{array}$ \\
\hline & & D.O. Rourke & 2004 & $\begin{array}{l}\text { Investors and shareholders also wish to obtain } \\
\text { complete information about non-financial risks } \\
\text { and liabilities. }\end{array}$ \\
\hline & & $\begin{array}{l}\text { S.O. Idowu, I. } \\
\text { Papasolomon }\end{array}$ & 2007 & $\begin{array}{l}\text { Stakeholders want to know how socially } \\
\text { responsible the organization is. }\end{array}$ \\
\hline & & G. Birth et al. & 2008 & $\begin{array}{l}\text { CSR reporting often promotes a company's } \\
\text { stock price or leads to increased trade in its } \\
\text { shares. }\end{array}$ \\
\hline & & L. Sweeney et al. & 2008 & $\begin{array}{l}\text { CSR reports as one of the communication } \\
\text { channels. Communication increases customer } \\
\text { loyalty, expands public support for the company, } \\
\text { eases the recruitment of talented employees, } \\
\text { and decreases the risk of reputational damage. }\end{array}$ \\
\hline & & Y. Gao & 2009 & $\begin{array}{l}\text { Companies listed on the stock exchange must } \\
\text { also provide information about CSR in their } \\
\text { financial statements. }\end{array}$ \\
\hline & & $\begin{array}{l}\text { A.W. } \\
\text { Sutantoputra }\end{array}$ & 2009 & $\begin{array}{l}\text { CSR reports are extremely important in making } \\
\text { business decisions. }\end{array}$ \\
\hline & & D.O. Rourke & 2004 & Growing demand for CSR investments. \\
\hline & & M. Marais & 2012 & $\begin{array}{l}\text { CSR communication is an essential element } \\
\text { of CSR development between organizations. }\end{array}$ \\
\hline \multirow[t]{3}{*}{2.} & \multirow{3}{*}{$\begin{array}{l}\text { Improving the } \\
\text { image and } \\
\text { reputation of the } \\
\text { company }\end{array}$} & $\begin{array}{l}\text { A.W. } \\
\text { Sutantoputra }\end{array}$ & 2008 & $\begin{array}{l}\text { Companies can develop a positive public } \\
\text { image. }\end{array}$ \\
\hline & & C.A. Adams & 2008 & $\begin{array}{l}\text { Companies try to enhance their reputation } \\
\text { through CSR reporting (which is one form } \\
\text { of image management). }\end{array}$ \\
\hline & & $\begin{array}{l}\text { D. Hildebrand } \\
\text { et al. }\end{array}$ & 2011 & $\begin{array}{l}\text { A company's communication, which is a set } \\
\text { of associations arising between stakeholders } \\
\text { in the company, affects its reputation. }\end{array}$ \\
\hline \multirow[t]{3}{*}{3.} & \multirow[t]{3}{*}{$\begin{array}{l}\text { Creating brand } \\
\text { value }\end{array}$} & D.O. Rourke & 2004 & $\begin{array}{l}\text { Consumers would agree to pay more for } \\
\text { a garment made by a company guided by social } \\
\text { and environmental standards. }\end{array}$ \\
\hline & & $\begin{array}{l}\text { R. Chomvilailuk, } \\
\text { K. Butcher }\end{array}$ & 2010 & $\begin{array}{l}\text { There is a positive relationship between CSR } \\
\text { and brand value creation - companies can gain } \\
\text { a clear competitive advantage, for consumers } \\
\text { are hoping that will match some social values, } \\
\text { not just be a quality product at a low price. }\end{array}$ \\
\hline & & $\begin{array}{l}\text { A. Ivanisevic } \\
\text { Hernaus, A. } \\
\text { Stojanovic }\end{array}$ & 2015 & $\begin{array}{l}\text { From banks' point of view social responsibility } \\
\text { in its comprehensive understanding is the way } \\
\text { of creating long-term value - recognize business } \\
\text { opportunities and manage risk more efficiently. }\end{array}$ \\
\hline
\end{tabular}




\section{Tab. 1: Reasons for CSR reporting identified in its research literature (Part 2)}

\begin{tabular}{|c|c|c|c|c|}
\hline No. & $\begin{array}{c}\text { Reasons for CSR } \\
\text { reporting }\end{array}$ & Author & Year & Benefits of CSR reporting \\
\hline \multirow[t]{7}{*}{4.} & \multirow[t]{7}{*}{$\begin{array}{l}\text { Increase } \\
\text { profitability } \\
\text { minimization of risk }\end{array}$} & D.O. Rourke & 2004 & $\begin{array}{l}\text { CSR reports can serve as a self-regulatory } \\
\text { instrument that helps to avoid future risks, } \\
\text { because the problems are managed } \\
\text { immediately after being identified. }\end{array}$ \\
\hline & & G. Birth et al. & 2008 & $\begin{array}{l}\text { Due to CSR reporting the uniqueness of the } \\
\text { product increases and companies can sell it } \\
\text { at a higher price. }\end{array}$ \\
\hline & & $\begin{array}{l}\text { J.D. Margolis } \\
\text { et al. }\end{array}$ & 2007 & $\begin{array}{l}\text { CSR reporting contributes to increasing } \\
\text { enterprise value. }\end{array}$ \\
\hline & & M. Plumlee et al. & 2010 & Improvement of cash flow. \\
\hline & & E. Dimson et al. & 2012 & Increases stock prices in large enterprises. \\
\hline & & K. Lang et al. & 2012 & Improvement in financial liquidity. \\
\hline & & $\begin{array}{l}\text { D. Martinčik, M. } \\
\text { Polívka }\end{array}$ & 2012 & $\begin{array}{l}\text { From the maximization of profits to the } \\
\text { maximization of shareholder value. }\end{array}$ \\
\hline \multirow[t]{4}{*}{5.} & \multirow[t]{4}{*}{$\begin{array}{l}\text { The element } \\
\text { of strategic } \\
\text { management }\end{array}$} & P. Jones et al. & 2007 & $\begin{array}{l}\text { CSR is an important element of strategic } \\
\text { management in helping companies to respond } \\
\text { to changes in business environment. }\end{array}$ \\
\hline & & R. Tewari & 2011 & $\begin{array}{l}\text { It is easier to confront a strong CSR } \\
\text { communication risk than where a business has } \\
\text { no idea about the extent, ways and accents } \\
\text { of communication. Companies also may fail } \\
\text { by choosing bad communication strategies. }\end{array}$ \\
\hline & & I. Pollach & 2012 & $\begin{array}{l}\text { A company signalling CSR only in a public } \\
\text { relations campaign, i.e. applying a superficial } \\
\text { rather than a deep rooted strategy, loses the } \\
\text { opportunity to get maximum benefits. }\end{array}$ \\
\hline & & $\begin{array}{l}\text { R.E. Hinson, } \\
\text { P. Kodua }\end{array}$ & 2012 & $\begin{array}{l}\text { Only an integrated company's strategy which } \\
\text { is unique and consistent with the company's } \\
\text { activities CSR practice will be useful. }\end{array}$ \\
\hline \multirow[t]{3}{*}{6.} & \multirow{3}{*}{$\begin{array}{l}\text { Providing } \\
\text { comparability of } \\
\text { CSR reports }\end{array}$} & A. Douglas et al. & 2004 & Comparability and transparency. \\
\hline & & O. Delbard & 2008 & Comparability and transparency. \\
\hline & & $\begin{array}{l}\text { V. Juscius, A. } \\
\text { Sneideriene, R. } \\
\text { Griauslyte }\end{array}$ & 2014 & $\begin{array}{l}\text { Only responsibly and professionally prepared } \\
\text { reports can act as powerful marketing tools } \\
\text { and means of helping to adopt CSR practice } \\
\text { in the marketing process. }\end{array}$ \\
\hline
\end{tabular}

Source: The authors' own compilation.

improved image and reputation, creation of brand value, as well as increasing profitability and minimising risks began to be cited. CSR became a major source of information for broadly-defined stakeholders, was used to manage enterprises and to generate benefits, including improved financial performance. These results were confirmed by the research of Margolis et al. (2007) that pointed to a link between environmental reporting and goodwill; research by Dimson et al. (2012), who recorded growth in the share prices of large enterprises; by Plumlee et al. (2010) who demonstrated improved cash flows; and by Lang et al. (2012), who traced a link between CSR and financial liquidity. The need to standardise CSR reporting 
in order to assure its comparability also began to be highlighted.

\section{Reasons for CSR Reporting in the Opinions of Enterprises}

The benefits of reporting non-financial information can be divided into two groups:

- Internal - reporting helps to streamline a range of processes in an enterprise by diagnosing problems. It also helps to maintain appropriate relations between market positioning of a product brand and its production, which influences the assessment of products and thus demand, market share and the profits of enterprises.

- External - reporting is a part of information policies that: reinforces the reliability of actions for and relations with stakeholders, helps to manage reputation risks and build competitive advantage.

These benefits are reflected in a survey by EY and Boston College Center for Corporate Citizenship (2013) with members of the Center for Corporate Citizenship and Survey Sampling International (SSI). There were 579 respondents in total - 391 of whom work for organizations that issue a sustainability report, and 188 for organizations do not issue reports.
The reasons for drafting CSR reports in the opinion of the respondents are summarised in Tab. 2.

An analysis of the reasons for preparing CSR reports demonstrates:

- Transparency with stakeholders is the principal reason, selected by all the entities examined, proof that the reporting is an important element of information policies and reporting itself is seen as part of the information.

- The organisations surveyed perceive reporting as a major part of risk management, which contributes to more efficient operations (an internal benefit), to building of reliability with stakeholders and to competitive advantage (external benefits).

- CSR reporting is not currently considered to be a marketing tool that would build brand (amongst large enterprises - 4\% of the organisations questioned disagreed, that rose to $5 \%$ in in finance and insurance). This reason should be expected to become more important over time.

- Some entities are not convinced it is reasonable to draft CSR reports ( $4 \%$ of large and $6 \%$ of smaller entities, $7 \%$ of public and $8 \%$ of private organisations). This means an

\section{Tab. 2: Reasons for CSR reporting (\%)}

\begin{tabular}{|c|c|c|c|c|c|c|c|c|c|c|}
\hline \multirow[b]{2}{*}{$\begin{array}{l}\text { Reasons for CSR } \\
\text { reporting }\end{array}$} & \multicolumn{2}{|c|}{ By company size } & \multicolumn{2}{|c|}{ By company type } & \multicolumn{6}{|c|}{ By company activity } \\
\hline & $\begin{array}{c}\text { Annual } \\
\text { revenues } \\
\text { over } \$ 5 \\
\text { billion }\end{array}$ & $\begin{array}{c}\text { Annual } \\
\text { revenues } \\
\text { under } \$ 5 \\
\text { billion }\end{array}$ & $\begin{array}{c}\text { Publicly } \\
\text { traded } \\
\text { for-profit } \\
\text { company }\end{array}$ & $\begin{array}{l}\text { Private } \\
\text { for-profit } \\
\text { company }\end{array}$ & $\mathrm{FI}$ & $\mathrm{H}$ & I & $M$ & $\mathbf{P}$ & U \\
\hline $\begin{array}{l}\text { Transparency with } \\
\text { stakeholders }\end{array}$ & 79 & 59 & 79 & 60 & 69 & 56 & 73 & 83 & 81 & 85 \\
\hline Risk management & 48 & 33 & 39 & 49 & 41 & 29 & 42 & 40 & 41 & 52 \\
\hline Stakeholder pressure & 46 & 25 & 38 & 29 & 22 & 8 & 38 & 45 & 27 & 38 \\
\hline Competitive advantage & 67 & 59 & 57 & 52 & 58 & 46 & 66 & 53 & 59 & 37 \\
\hline Brand/reputation & 4 & - & 2 & 1 & 5 & - & 3 & 1 & - & 8 \\
\hline Company culture & 6 & 7 & 7 & 8 & 12 & 5 & 10 & 6 & 5 & 5 \\
\hline Other & 11 & 8 & 13 & 5 & - & - & - & - & - & - \\
\hline I'm not sure & 4 & 6 & 7 & 8 & - & - & - & - & - & - \\
\hline
\end{tabular}

Note: FI - Finance and Insurance, $\mathrm{H}$ - Health care and social assistance, I - Information,

$\mathrm{M}$ - Manufacturing, $\mathrm{P}$ - Professional scientific and technical services, $\mathrm{U}-$ Utilities and mining. 
Tab. 3: Reasons why companies do not report (\%)

\begin{tabular}{l|c|c}
\multicolumn{1}{c|}{ Reasons why companies do not report } & $\begin{array}{c}\text { Publicly traded for-profit } \\
\text { companies }\end{array}$ & $\begin{array}{c}\text { Private for-profit com- } \\
\text { panies }\end{array}$ \\
\hline No one is asking for this information & 26 & 45 \\
\hline $\begin{array}{l}\text { We intend to do so, but have not have the } \\
\text { resources to prepare a public report }\end{array}$ & 51 & 18 \\
\hline $\begin{array}{l}\text { We track this information internally, but elect } \\
\text { not to publish it }\end{array}$ & 19 & 29 \\
\hline We consider the information proprietary & 6 & 18 \\
\hline
\end{tabular}

Source: The authors' own compilation on the basis of EY (2013).

absence of obligatory reporting undermines its rationale; in addition, organisations employ other forms of communication with stakeholders and find them adequate.

It is also interesting to analyse the reasons for not compiling CSR reports by $30 \%$ of the organisations examined (Tab. 3).

The survey shows that $51 \%$ of public and $18 \%$ of private organisations which do not report indicated absence of resources on which to base reports - which unequivocally points to a clear need to define rules of preparation, or reporting standards. $45 \%$ of private and $26 \%$ of public entities that do not report indicated a lack of stakeholder requirements as a reason proof that the idea of CSR and the significance of the associated information policies are misunderstood. These organisations do not realise the potential benefits they could attain by compiling CSR reports.

In general, the introduction of compulsory CSR reporting and the definition of its standards would contribute to the development of the idea of CSR and improve the information policies of enterprises by ensuring their comparability and legitimacy.

\section{Standardisation of Non-Financial Information}

The fundamental reason for standardising nonfinancial information reporting is to improve the transparency of social and environmental information supplied by reporting organisations, in order to assure its comparability both across sectors and internationally. Non-financial information disclosed assists enterprises with measurement, supervision and management with reference to financial performance and its impact on the public, and to help to satisfy the needs of investors and other interested parties, including consumers, as far as access to information about public impact of an enterprise is concerned. It is therefore valuable both to enterprises themselves and to a wide range of external and internal stakeholders. Legal systems laying down guidelines for CSR reporting vary considerably, however, which impedes comparability across enterprises and prevents assessments of their actions and the CSR principles adopted. It would therefore be desirable to develop international rules of CSR reporting, including the format and scope of reporting, which would provide for a transparent message of CSR-related activities.

Two models of CSR reporting can be distinguished:

- voluntary, supported mainly by corporations (Rodriquez \& LeMaster, 2007; Francis, Nanda, \& Olsson, 2008; Dhaliwal, Li, Tsang, \& Yang, 2009),

- compulsory, mainly promoted by nongovernment organisations, pressure groups and trade unions (Doane, 2002; Maguire, 2011; loannou \& Serafeim, 2011).

Specialist literature offers arguments both for and against these models of CSR reporting. Proponents of compulsory reporting usually point to fostering of socially responsible management practices (loannou \& Serafeim, 2011; Porter \& Kramer, 2011) and transparency of the reports (Elkington \& Spencer-Cooke, 1997; Gray, 2007; Doane, 2008; DeSilva, 2008; Lydenberg, Rogers, \& Wood, 2010; Gray \& Bebbington, 2010).

Opponents of compulsory reporting most frequently stress costs of the reporting, associated both with compilation of a report in itself and with monitoring of the reporting 
process (Schaltegger, 1997; CGA, 2011; Centre for Strategy and Evaluation Services, 2011) as well as utility of the reports - fulfilment of only minimum regulatory requirements contributes to neglecting the process of gathering and analysing CSR data, which leads to the undesirable outcome of low-quality information displacing high-quality information (Schaltegger, 1997; Herzig \& Schaltegger, 2006). Obviously, each of the models has its advantages and disadvantages (Tab. 4).

\begin{tabular}{|c|c|c|}
\hline $\begin{array}{l}\text { Adva } \\
\text { repor }\end{array}$ & \multicolumn{2}{|c|}{$\begin{array}{l}\text { Advantages and disadvantages of compulsory and voluntary model of CSR } \\
\text { reporting }\end{array}$} \\
\hline $\begin{array}{c}\text { Model of CSR } \\
\text { reporting }\end{array}$ & Advantages & Disadvantages \\
\hline Compulsory & $\begin{array}{l}\text { - } \text { comparability of reports, } \\
\text { management practices. }\end{array}$ & $\begin{array}{l}\text { - inflexibility, } \\
\text { individual nature of a reporting } \\
\text { entity is not taken into } \\
\text { consideration, } \\
\text { - limitation to minimum regulatory } \\
\text { requirements and neglect } \\
\text { of analysis of CSR data - lower } \\
\text { quality of information, } \\
\text { - costs of reporting. }\end{array}$ \\
\hline Voluntary & $\begin{array}{l}\text { - } \text { flexibility, } \\
\text { individual nature of a reporting } \\
\text { entity is taken into consideration. }\end{array}$ & $\begin{array}{l}\text { voluntary selection of: reporting } \\
\text { periods, ratios to disclose, forms } \\
\text { of presentation, } \\
\text { - incomparability of reports, } \\
\text { - incomplete. }\end{array}$ \\
\hline
\end{tabular}

Source: The authors' own compilation.

Analysis of global trends in CSR reporting shows about two thirds of 140 national standards, both compulsory and voluntary, identified in 30 countries are compulsory (KPMG, UNEP, GRI, University of Stellenbosch, 2010). The need to standardise principles and, at least partly (e.g. by industry), formats of CSR reporting is clear, therefore, as it would preserve flexibility and individuality of enterprises. It is difficult to subscribe to views of Herzig and Schaltegger (2006), however, that fulfilment of barely minimum regulatory requirements contributes to neglecting the process of gathering and analysing CSR data and leads to low quality of information. Introduction of compulsory reporting of non-financial information and its appropriate standardisation will contribute to improved quality of the information as it will provide for a standard presentation and comparability of data. It will not necessarily mean, as indicated by Herzig and Schaltegger (2006), neglecting the process of gathering and analysing CSR data. Conversely, maintenance of data transparency and legibility prevents all data from being presented in external reports since too much information is as inadequate as its absence.

The practice of enterprises publicising their CSR initiatives shows this information is communicated via: mass media, financial reports including incomplete and random CSR information, social or integrated reporting. These are very different practices, a result of the lack of any standard regulations of CSR reporting globally, continentally or nationally. Enterprises compile CSR reports according to a variety of guidelines, e.g. the Global Reporting Initiative (GRI), ISO 26000, Global Compact, and the Carbon Disclosure Project. Reporting in line with the GRI standards is the most common (Lament, 2015; Marková, Lament, \& Wolak-Tuzimek, 2015).

Research into corporate social responsibility by the European Commission (2013) points to two major problems:

- Insufficient transparency of nonfinancial information, due both to market imperfections and regulatory gaps, the 
latter caused by an absence of appropriate legal regulations,

- Lack of diverse membership of management boards, a result of inappropriate recruitment practices for management bodies recruitment of candidates with similar profiles. This contributes to ineffective control and supervision of management decisions, due to uniform viewpoints, value systems and competences, and restricts corporate innovation.

To address these issues, the European Commission has passed Directive 2014/95/ EU, to be introduced by the member states by 6 December 2016 and applicable to the relevant businesses during the financial year beginning on 1st January 2017 or during the calendar year 2017.

Directive 2014/95/EU applies to large enterprises of public interest, i.e. quoted companies, insurance companies, banks and other organisations of public importance in view of their business profile and employing more than 500 staff on average in a financial year as at the balance closing date.

Pursuant to Art. 1 section 1 item 1 of EU Directive, the organisations concerned shall include in their reports non-financial information, including information required to understand the development, results and position of the organisation and the impact of its operations in respect of environmental and social issues, respect for human rights, counteracting bribery and corruption, including:

- A brief description of the business model.

- A description of practices with regard to such issues, including due diligence processes in place.

- The outcomes of these practices.

- The chief risks associated with these issues and with the operations of the organisation.

- The key non-financial performance indicators relating to a given business.

Notably, reporting organisations:

- Must, as a minimum, provide explanations if they do not follow any policies in respect of the foregoing issues.

- By way of exception, may omit information about expected occurrences or matters subject to negotiations in progress if their disclosure might have a seriously adverse effect on commercial position of an organisation while having no impact on a correct and objective understanding of the development, performance and position of the organisation and the impacts of its activities.

- Can rely on national, EU or international framework principles. These should be specified in the circumstances.

- May be free from the duty to report nonfinancial information if they prepare a separate report which is published together with financial statements, or on the organisation's website, within six months of the balance closing date, and if financial statements contain a reference to such a report.

The regulations of the Directive are a step forward since they will help to standardise the rules of reporting non-financial information, and will improve its transparency and utility. They will largely apply to organisations that already compile such reports in the spirit of CSR, and a lack of detailed regulations would impede their comparability, since organisations could rely on different rules and guidelines. Thus, the Directive 2014/95/EU fills a regulatory gap and improves the usefulness of the information generated by organisations obliged to prepare CSR reports.

\section{Reporting of Non-Financial Information in 2010-2014}

Enterprises submitting CSR reports to GRI (Global Reporting Initiative) in 2010-2014 were surveyed in order to determine trends in CSR reporting and to evaluate the extent of its standardisation. The numbers and structure of the reports were analysed by region and by enterprise size. The criteria were considered jointly and separately, that is, rules of CSR reporting across global regions were examined by size of enterprise.

The figures concerning CSR reports are divided into reports following the GRI guidelines and those based on other rules and guidelines.

Principles of classifying organisations according to GRI assumptions are presented in Tab. 5.

The research implies:

1. CSR reports commonly follow the GRI guidelines (93.5\% organisations questioned in $2010,79 \%$ in 2012 , and $77.1 \%$ in 2014 ). A declining trend is observed, though, which suggests other reporting guidelines have been gaining popularity $(2010-6.5 \%$, $2012-21 \%, 2014-22.9 \%)$ - Fig. 1. 
Tab. 5: Principles of classifying organisations according to GRI assumptions

\begin{tabular}{c|c|c|c} 
Size of organisation & Headcount & Revenue & Balance sheet total \\
\hline SME & Up to 250 & Up to $€ 50 \mathrm{~m}$ & Up to $€ 43 \mathrm{~m}$ \\
\hline Large & Above 250 & Above $€ 50 \mathrm{~m}$ & Above $€ 43 \mathrm{~m}$ \\
\hline MNE & Above 250 (of various nationalities) & Above $€ 50 \mathrm{~m}$ & Above $€ 43 \mathrm{~m}$ \\
\hline
\end{tabular}

\section{Fig. 1: Changes of structure of CSR reporting in 2010-2014 (\%)}

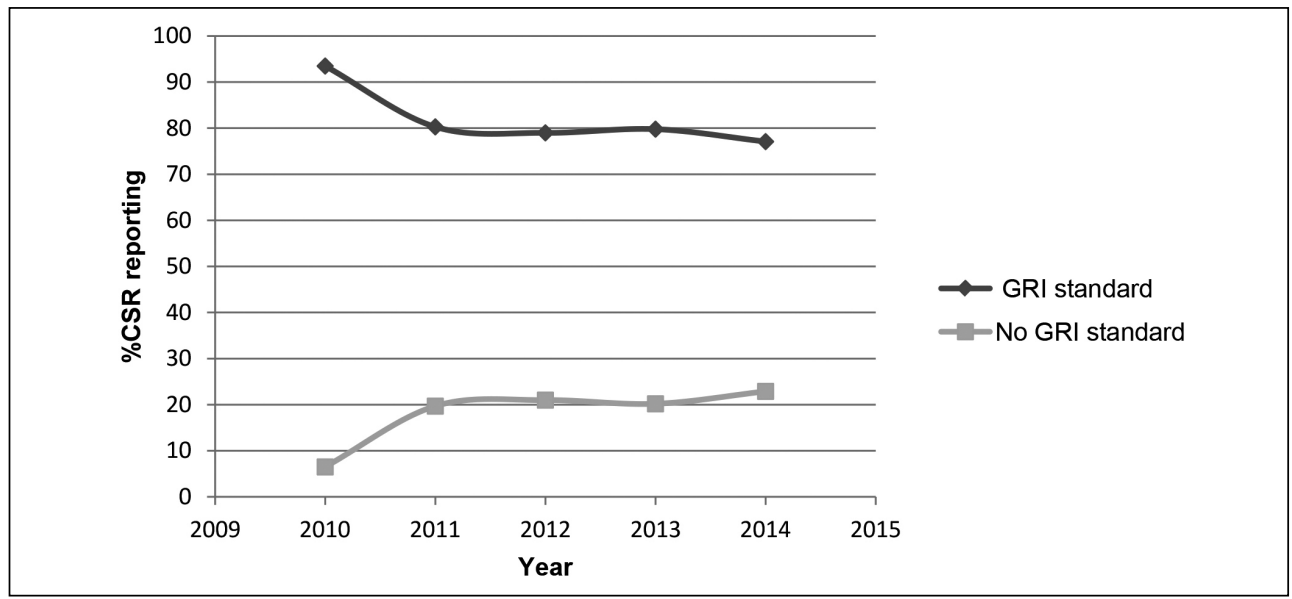

Source: The authors' own research on the basis of GRI, Sustainability Disclosure Database

\section{Fig. 2: Structure of reports submitted to GRI across regions in 2010 (\%)}

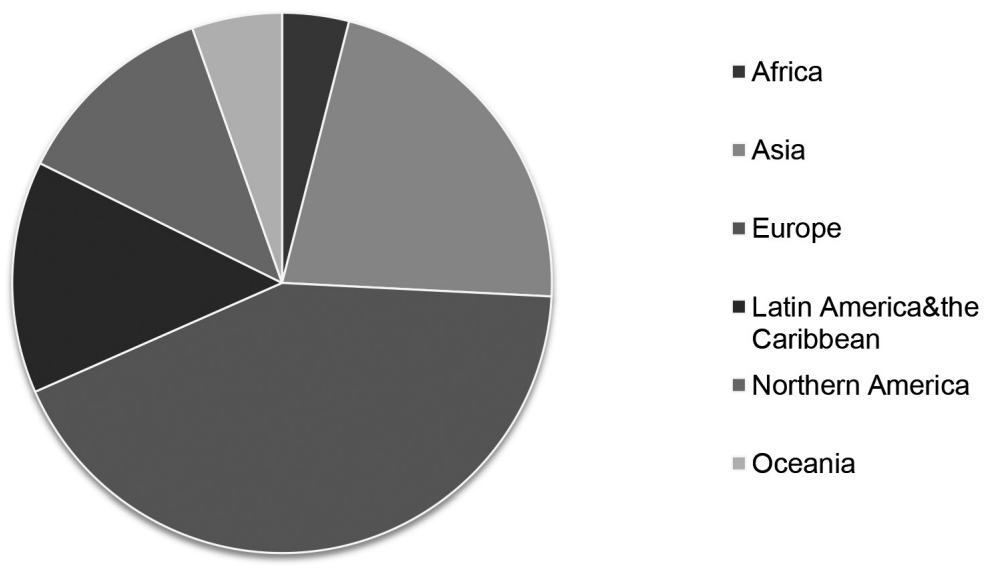

Source: The authors' own research on the basis of GRI, Sustainability Disclosure Database 
2. A majority of CSR reports are compiled by enterprises in Europe $(2010-42.6 \%$ of the organisations examined, $2012-38 \%$, $2014-34.9 \%$ ). A declining trend can be observed, though, which means CSR reporting is expanding intensely in other regions, mainly in Asia (2014 - 25.6\% of the organisations surveyed, $2012-23.1 \%$, $2010-21.8 \%)$ and Africa (2010 - 4\%, 2012
$-8.9 \%, 2014-7.2 \%)$. Increasing numbers of reports are drafted in the remaining regions, yet the growth is not sufficient to affect the structure of the reporting (Latin America - approximately $13 \%$ of the reports in the entire period under analysis, North America - 13-14\% depending on the year, Oceania $-3-5 \%$ depending on the year) Figs. 2-4.

\section{Fig. 3: Structure of reports submitted to GRI across regions in 2012 (\%)}

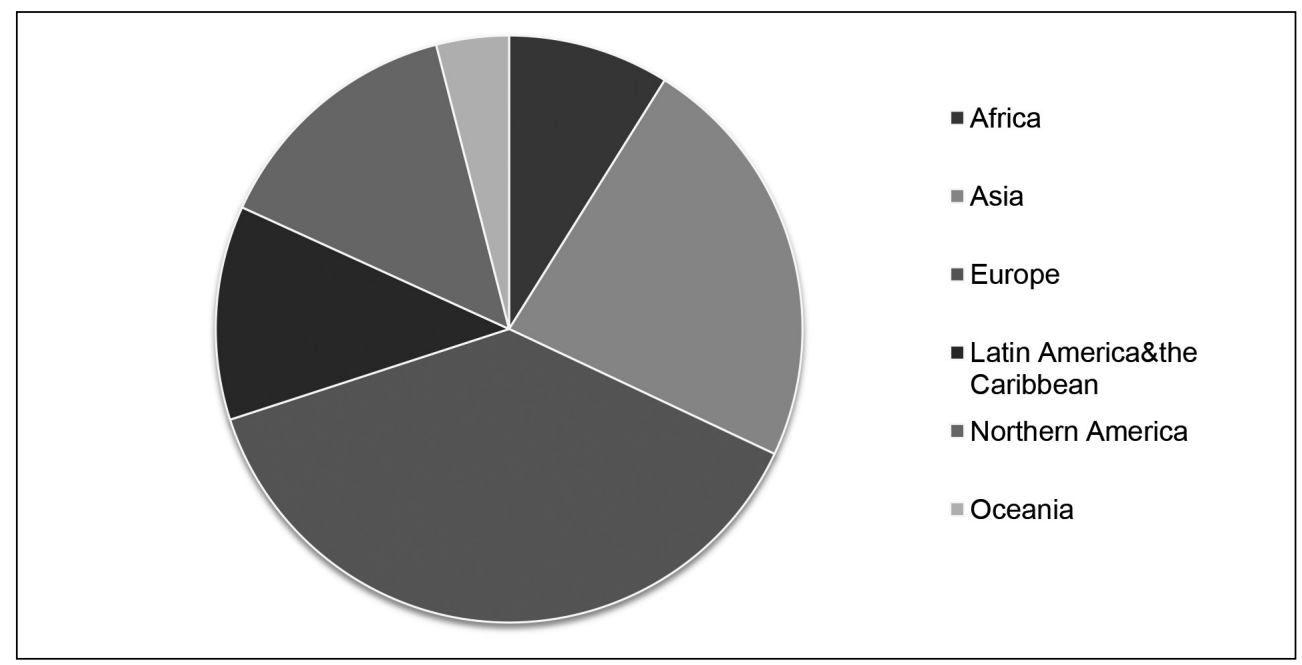

Source: The authors' own research on the basis of GRI,

Sustainability Disclosure Database.

3. The reports are most frequently compiled by large enterprises, accounting for $68.6 \%$ in $2010,64.9 \%$ in 2012 , and $64 \%$ in 2014 . Their share in the structure of reporting has been diminishing, proof that the reporting is gaining importance with other organisations, chiefly MNEs (in $2010-20 \%$ of the organisations questioned, $2012-23.8 \%$, and $2014-25.2 \%$ ). Numbers of reports submitted by SMEs are not sufficiently large to affect the structure of reporting. Their share reached: $11.4 \%$ in $2010,11.3 \%$ in 2012 and $10.8 \%$ in 2014 - Tab. 6.

4. Large enterprises preparing CSR reports operate mainly in Europe (2010 - 42.7\%, 2012 - 35.3\%, $2014-35 \%)$ and Asia (2010 $-21.5 \%, 2012-24.9 \%, 2014-27.4 \%)$. The proportion of reporting enterprises has been climbing in Asia and falling in Europe - Fig. 5.

5. SMEs reporting under CSR, like large enterprises, chiefly operate in Europe (2010 $-60.6 \%$ of SMEs examined, $2012-55.6 \%$, $2014-52.6 \%$ ) - Fig. 6.

6. MNEs enterprises preparing CSR reports operate mainly in Europe (2010 - 32.4\%, $2012-33.7 \%, 2014-34.9 \%)$ and Asia (2010 - 30\%, 2012 - 34\%, $2014-26.5 \%)$. The proportion of reporting enterprises has been climbing in Europe and falling in Asia - Fig. 7.

7. Both large enterprises, SMEs and MNEs draft their reports not only in compliance with the GRI guidelines, as the incidence of reporting based on other guidelines has been growing substantially: 


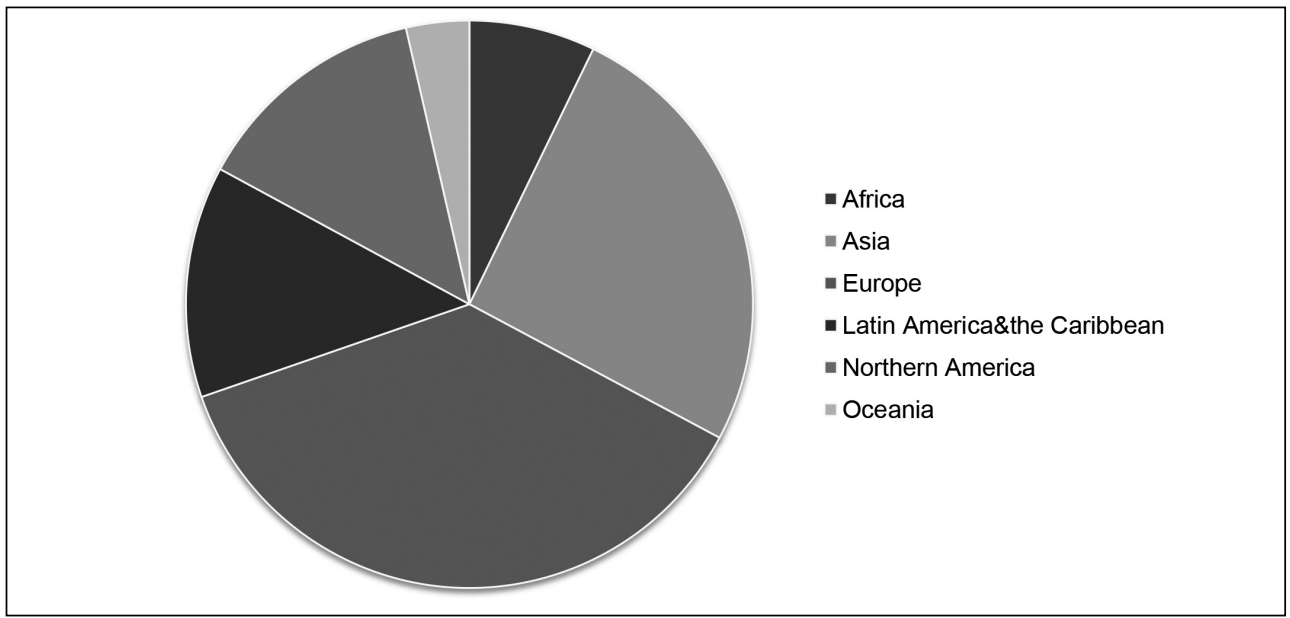

Source: The authors' own research on the basis of GRI, Sustainability Disclosure Database.

\section{Tab. 6: Structure of reports submitted to GRI in 2010-2014 by size of organisation}

\begin{tabular}{l|c|c|c|c|c|c}
\multirow{2}{*}{ Specification } & \multicolumn{2}{c|}{2010} & \multicolumn{2}{c|}{2012} & \multicolumn{2}{c}{2014} \\
\cline { 2 - 7 } & quantity & $\%$ & quantity & $\%$ & quantity & $\%$ \\
\hline $\begin{array}{l}\text { SME - reporting as per GRI } \\
\text { standard }\end{array}$ & 241 & 11.0 & 357 & 9.0 & 359 & 8.0 \\
\hline SME - No GRI reports & 8 & 0.4 & 89 & 2.3 & 127 & 2.8 \\
\hline $\begin{array}{l}\text { Large - reporting as per GRI } \\
\text { standard }\end{array}$ & 1,413 & 64.6 & 2,033 & 51.6 & 2,296 & 50.9 \\
\hline Large - No GRI reports & 88 & 4.9 & 524 & 13.3 & 589 & 13.1 \\
\hline $\begin{array}{l}\text { MNE - reporting as per GRI } \\
\text { standard }\end{array}$ & 415 & 18.9 & 720 & 18.3 & 855 & 19.0 \\
\hline MNE - No GRI reports & 24 & 1.1 & 217 & 5.5 & 281 & 6.2 \\
\hline $\begin{array}{l}\text { Total reporting as per GRI } \\
\text { standard }\end{array}$ & 2,072 & 94.5 & 3,110 & 78.9 & 3,510 & 77.9 \\
\hline Total - No GRI reports & 120 & 5.5 & 830 & 21.1 & 998 & 22.1 \\
\hline
\end{tabular}

Source: The authors' own research on the basis of GRI, Sustainability Disclosure Database

$\square$ SME (2010 - 3.6\%, $2012-20.4 \%$, $2014-26.8 \%)$.

$\square \quad$ Large enterprises (2010 - 7\%, 2012 $20.6 \%, 2014-21 \%)$.

$\square \quad$ MNE (2010 - 6.4\%, $2012-23.5 \%$, $2014-29.9 \%)-$ Fig. 8 .

This tendency is reaffirmed by an analysis of the enterprises in those regions with the most distinct growth:

- SME - in North American enterprises (2010 $-0.4 \%, 2014-5.4 \%$ of SMEs reviewed),

- Large enterprises - in European enterprises $(2010-2.7 \%, 2014-7.4 \%$ of the large enterprises examined),

- MNE - in European enterprises (2010 $2 \%, 2014-9.7 \%$ of MNEs surveyed). 


\section{Ekonomika a management}

Fig. 5:

Structure of reports prepared by large enterprises submitted to GRI in 2010-2014 across regions (\%)

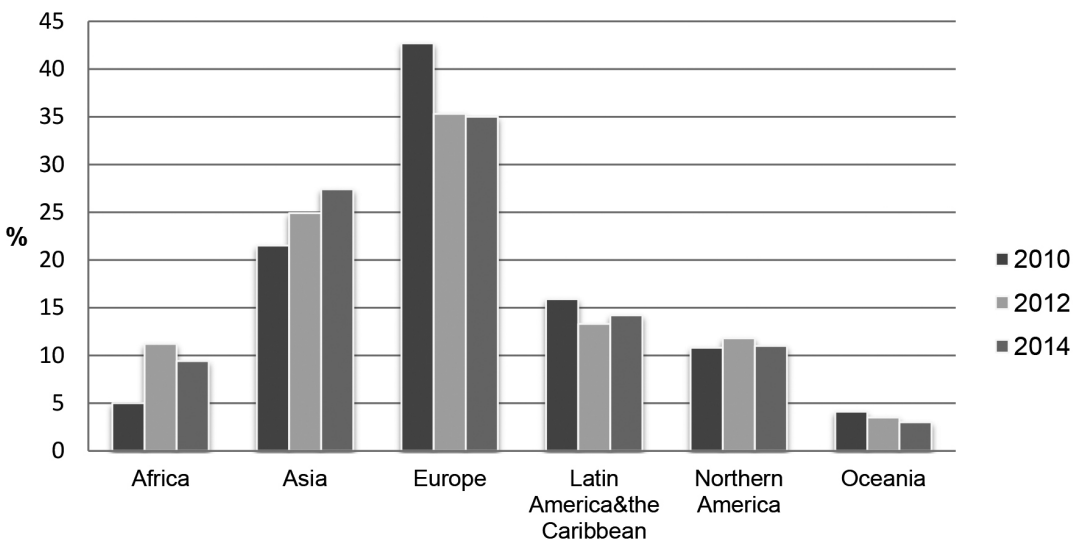

Region

Source: The author's own research on the basis of GRI, Sustainability Disclosure Database.

\section{Fig. 6:}

\section{Structure of reports prepared by SME enterprises submitted to GRI} in 2010-2014 across regions (\%)

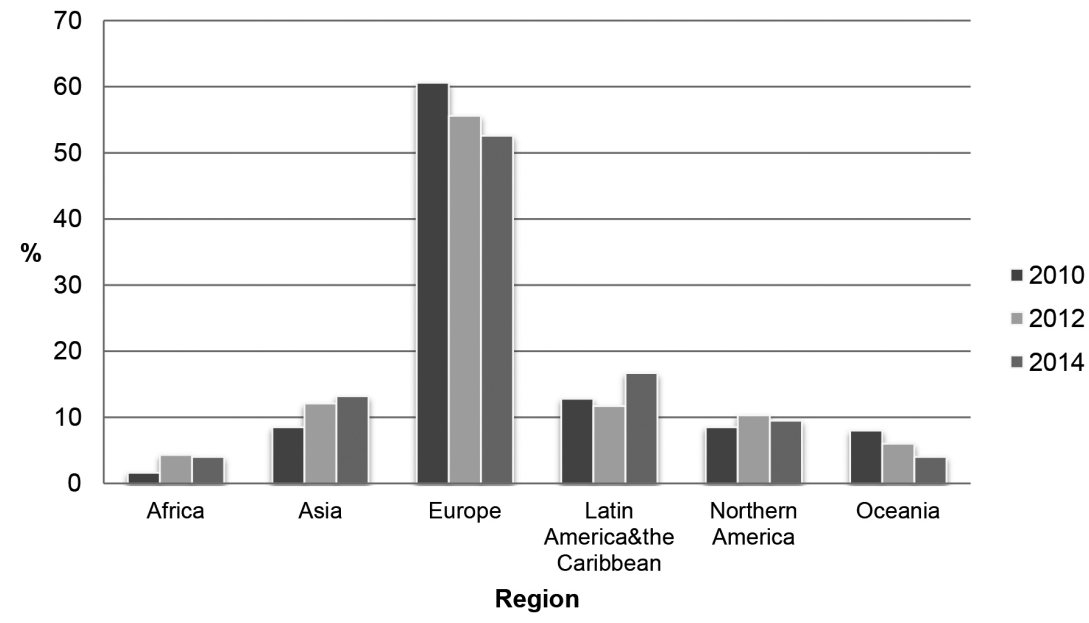

Source: The authors' own research on the basis of GRI, Sustainability Disclosure Database. 


\section{Fig. 7: Structure of reports prepared by MNE to GRI in 2010-2014 across regions}

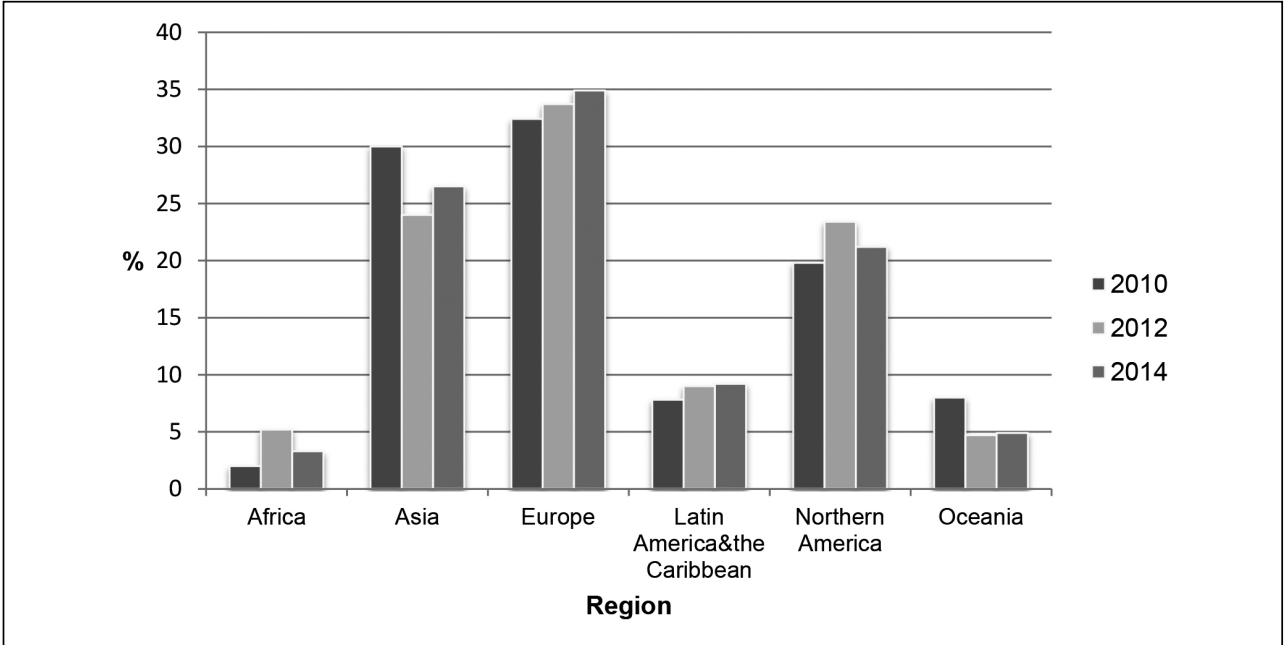

Source: The authors' own research on the basis of GRI, Sustainability Disclosure Database.

\section{Fig. 8:}

CSR reporting as per standards other than GRI by enterprises size 2010-2014 (\%)

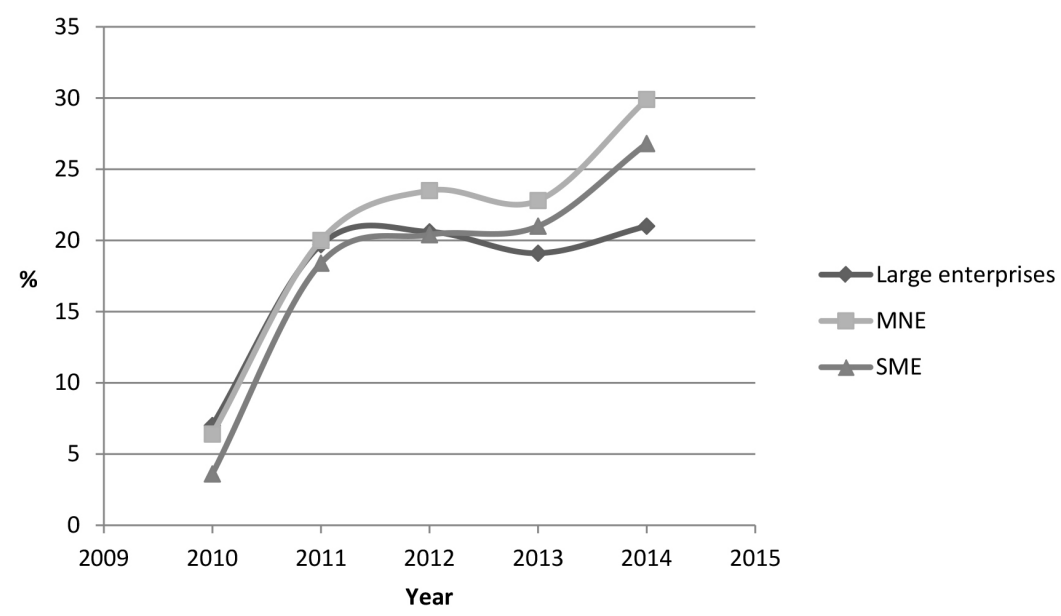

Source: The authors' own research on the basis of GRI, Sustainability Disclosure Database. 


\section{Conclusion}

Presentation of non-financial information helps to identify issues important to a given entity and the associated risks. This is additional information, not clearly visible in financial reports since, in accordance with the principle of significance, only events with significant impact on operations and financial standing of an enterprise should be disclosed. If an entity fails to recognise environmental and social developments as significant to its financial position and its activities, they will not be presented in financial statements either. Therefore, absence of publication duties concerning non-financial information should be regarded as contributing to emergence of the information asymmetry.

It should be pointed out not only reporting in itself but also its scope and principles are important to stakeholders, including investors. In order to limit the information asymmetry, nonfinancial data should be presented:

- to an adequate extent - it is important to determine types of information to be disclosed. Both information gaps and excess information are inadvisable, both producing similar effects. Information to be disclosed should be specified, therefore,

- in an appropriate form - to assure comparability and transparency of the disclosures,

- according to standards defined e.g. for specific industries.

Non-financial information must be said to constitute an important part of the decisionmaking process in an enterprise, therefore, lack of a duty to report it contributes to emergence of the information asymmetry, since various entities hold information of different quality. In order to limit the information asymmetry, the duty of reporting non-financial information should be introduced and standards of nonfinancial reporting must be laid down.

The literature review and empirical research into motivations for CSR reporting and trends in reporting of non-financial information have helped to verify the hypotheses formulated initially:

1. Communication with stakeholders is the fundamental reason for reporting nonfinancial information. This is confirmed by the literature review, with most authors believing this is the prime reason for preparing CSR reports. Authors indicating other motivations treat it as the fundamental cause which obtains jointly with other motivations.

This is also supported with results of the survey among enterprises compiling CSR reports - all the enterprise groups queried commonly point to this reason for CSR reporting.

2. The need to standardise CSR reporting to ensure its transparency and clarity is noted by reporting organisations. This is proven by surveys of organisations drafting CSR reports - approximately $80 \%$ of all reports follow the GRI guidelines, which thus become the most popular rules of reporting. This means the reporting enterprises wish their reports to be clear, transparent and comparable and for their stakeholders to be able to fully satisfy their information requirements. This is also evidence of the care for good relations with stakeholders, who receive standardised data although this is not binding on enterprises. A growing tendency for CSR reporting to follow guidelines other than the GRI can also be noted in the entire period under analysis - another argument for specifying rules of reporting and introducing standards. This will not necessarily be a single compulsory standard, yet a model report would need to be set to assure transparency and comparability.

This is addressed by Directive 2014/95/ EU, applicable only to large enterprises employing more than 500 staff, nonetheless it fills a regulatory gap, will contribute to improved comparability of results and will improve utility of information generated by enterprises drafting CSR reports.

It would be reasonable to continue the research by reviewing norms and standards of CSR reporting by enterprises active in particular industries, as this would help to define their characteristic norms and standards that could subsequently be standardised.

\section{References}

Adams, A.C. (2008). A Commentary on: corporate social responsibility reporting and reputation risk management. Accounting, Auditing \& Accountability Journal, 21(3), 365370. doi:10.1108/09513570810863950.

Berle, A.A. (1931). Corporate Powers as Powers in Trust. Harvard Law Review, 44, 1049-1-79. 
Birth, G., Illia, L., Laurati, F., \& Zamparini, A. (2008). Communicating CSR: practices among Switzerland's top 300 companies. Corporate Communication: An International Journal, 13(2), 182-196. doi:10.1108/13563280810869604.

Carroll, A.B. (1979). A Three Dimensional Conceptual Model of Corporate Social Performance. Academy of Management Review, 4(4), 497-505. doi:10.5465/AMR.1979.4498296.

Centre for Strategy and Evaluation Services. (2011). Disclosure of non-financial information by companies. Final report. Retrieved June 4, 2015, from http://ec.europa.eu/internal_ market/acconting/docs/non-financial-reporting/ com_2013_207-study_en.pdf.

CGA. (2011). Regulating Sustainability Reporting - Is a Mandatory Approach Better than Voluntary One? Retrieved June 4, 2015, from http:// www.cga-canada.org/en-ca/ResearchReports/ ca_rep_2011-12_informed-view.pdf.

Chomvilailuk, R., \& Butcher, K. (2010). Enhancing brand preference through corporate social responsibility initiatives in the Thai banking sector. Asia Pacific Journal of Marketing and Logistics, 22(3), 397-418. doi:10.1108/13555851011062296.

Deegan, C., \& Unerman, J. (2011). Financial Accounting Theory. New York: McGraw - Hill Education.

Delbard, O. (2008). CSR legislation in France and the European regulatory paradox: an analysis of EU CSR policy and sustainability reporting practice. Corporate governance, 8(4), 397-405. doi:10.1108/14720700810899149.

DeSilva, T.A. (2008). Voluntary Environmental Reporting: The Why, What and How. Retrieved June 4, 2015, from http:// researcharchive.linciln.ac.nz/dspace/ bitstream/10182/928/3DeSolva.phd.pdf.

Dhaliwal, D., Li, O.Z., Tsang, A.H., \& Yang, Y.G. (2009). Voluntary non-financial disclosure and the cost of equity capital: The case of corporate social responsibility reporting (Working Paper University of Arizona). Tucson: University of Arizona. Retrieved June 4, 2015, from http:// papers.ssrn.com/sol3/papers.cfm?abstract _id=1343453.

Dimson, E., Karakas, O., \& Li, X. (2012). Active ownership. Social Science Research Network. Retrieved June 4, 2015, from http:// www.people.hbs.edu/kramanna/HBS_JAE_ Conference/Dimson_Karakas_Li.pdf.

Directive 2014/95/EU of the European Parliament and of the Council of 22 October
2014 amending Directive 2013/34/EU as regards disclosure of non-financial and diversity information by certain large undertakings and groups, Official Journal of the European Union L330/1.

Doane, D. (2002). Market failure the case for mandatory social and environmental reporting. Retrieved June 5, 2015, from http://www. hapinternational.org/pool/files/doanepaper1.pdf.

Doane, D. (2008). Corporate Spin: The Troubled Teenage Years of Social reporting. London: New Economics Foundation.

Dodd, E.M. (1932). For Whom Are Corporate Managers Trustees? Harvard Law Review, 45, 1145-1163.

Douglas, A., Doris, J., \& Brian, J. (2004). Corporate social reporting in Irish financial institutions. The TQM Magazine, 16(6), 387395. doi:10.1108/09544780410563301.

European Committee. (2011). Green Paper. Promoting a European Framework for Corporate Social Responsibility.

European Parliament, Committee of Legal Affairs. (2013). Report on Corporate Social Responsibility: accountable, transparent and responsible business behavior and sustainable growth (2012/2098/INI). Retrieved May 5, 2015 from http://www.europarl. europa.eu/sides/getDoc.do?pubRef $=-/ /$ EP//NONSGML +REPORT + A 7-20130017+0+DOC+PDF+V0//EN.

Elkington, J., \& Spencer-Cooke, A. (1997). How do we measure up? Tomorrow. 6(1), 42-47.

European Parliament, Committee on Employment and Social Affairs. (2013). Report on Corporate Social Responsibility: promoting society's interest and a route to sustainable and inclusive recovery (2012/2097/ INI). Retrieved May 5, 2015, from http:// www.europarl.europa.eu/sides/getDoc. do?pubRef=-//EP//NONSGML+REPORT+A72013-0023+0+DOC+PDF+VO//EN.

EY, \& Boston College Center for Corporate Citizenship. (2013). Value of sustainability reporting. Retrieved June 5, 2015, from http:// www.ey.com/Publication/vwLUAssets/EY _Value_of_sustainability_reporting/\$FILE/EYValue-of-Sustainability-Reporting.pdf.

Francis, J., Nanda, D., \& Olsson, P. (2008). Voluntary Disclosure, Earnings Quality, and Cost of Capital. Journal of Accounting Research, 46(1), 53-99. doi:10.1111/j.1475679X.2008.00267.

Freeman, R.E. (1984). Strategic 
Management: A Stakeholder Approach. Boston: Pitman Publishing.

Gao,Y.(2009). Corporatesocial responsibility and consumers' response: the missing linkage. Baltic Journal of Management, 4(3), 269-287. doi:10.1108/17465260910990984.

Gray, R. (2007). Talking a long view on what we now know about social and environmental accountability and reporting. Issues in Social and Environmental Accounting, 1(2), 169-178.

Gray, R., \& Bebbington, J. (2010). Environmental Accounting, Managerialism and Sustainability: Is the Planet Safe in the Hands of Business and Accounting? In Gray, J., Bebbington, S., \& Gray, S. (Eds.), Social and Environmental Accounting. Los AngelesLondon-New Delhi-Singapore-Washington DC: Sage Publications.

GRI. Second G4 Public Comment. Retrieved June 5, 2015, from https://www.globalreporting. org/resourcelibrary/G4-Exposure-Draft.pdf.

GRI. Sustainability Disclosure Database. Retrieved June 5, 2015, from http://database. globalreporting.org.

Herzig, C., \& Schaltegger, S. (2006). Corporate Sustainability Reporting. An overview. In Schaltegger, S., Bennett, R., \& Burritt, R. (Eds.), Sustainability Accounting and Reporting. Dordrecht: Springer.

Hildebrand, D., Sen, S., \& Bhattacharrya, C.B. (2011). Corporate social responsibility: a corporate marketing perspective. European Journal of Marketing, 45(9/10), 1353-1364. doi:10.1108/03090561111151790.

Hinson, R.E., \& Kodua, P. (2012). Examining the marketing-corporate social responsibility nexus. International Journal of Law and Management, 54(5), 332-344. doi:10.1108/17542431211264223.

Horehajova, M., \& Marasova, J. (2008). The institutional factors of the Corporate Social Responsibility development in the Central European countries. E\&M Ekonomie a Management, 11(2), 58-63.

Idowu, S.O., \& Towler, B.A. (2004). A comparative study of the contents of corporate social responsibility reports of UK companies. Management of Environmental Quality: An International Journal, 15(4), 420437. doi:10.1108/14777830410540153.

Idowu, S.O., \& Papasolomou, I. (2007). Are the corporate social responsibility matters based on good intentions or false pretences? An empirical study of the motivations behind the issuing of CSR reports by UK companies. Corporate governance, 7(2), 136-147. doi:10.1108/14720700710739787.

Ioannou, I., \& Serafeim, G. (2011). The Consequences of Mandatory Corporate Sustainability Reporting (Working Paper). Harvard Business School. Retrieved June 5, 2015, from http://hbswk.hbs.edu/item/6691. html.

ISO 26000:2010. International Standard: Guidance on social responsibility. ISO 2010.

Ivanisevic, A., \& Stojanovic, A. (2015). Determinants of bank Social Responsibility: case of Croatia. E\&M Ekonomie a Management, 18(2), 117-134. doi: 10.15240/tul/001/2015-2009.

Jones, P., Comfort, D., \& Hillier, D. (2006). Reporting and reflecting on corporate social responsibility in the hospitality industry. A case study of pub operators in the UK. International Journal of Contemporary Hospitality Management, 18(4), 329-340. doi:10.1108/09596110610665339.

Jones, P., Comfort, D., \& Hillier, D. (2007). Marketing and corporate social responsibility within food stores. British Food Journal, 10(8), 582-593. doi:10.1108/00070700710772381.

Juscius, V., Sneideriene, A., \& Griauslyte, R. (2014). Assesment of the benefits of Corporate Social Responsibility reports as one of the marketing tools. Regional Formation and Development Studies, 11(3), 88-99. doi:10.15181/rfds.v11i3.612.

KPMG, United Nations Environment Programme, Global Reporting Intiative, University of Stollenbosch. (2010). Carrots and Sticks - Promoting transparency and sustainability. An update on trends in Voluntary and Mandatory Approaches to Sustainability Reporting. Retrieved May 5, 2015, from https:// www.globalreporting.org/resourcelibrary/ Carrots-And-Sticks-Promoting-TransparencyAnd-Sustainability.pdf.

Krištofik, P., Lament, M., Musa, H., \& Wolak-Tuzimek, A. (2015). Financial tools in management of small and medium-sized enterprises. London: SCIEMCEE Publishing London.

Lament, M. (2015). Trends in Corporate Social Responsibility (CSR) reporting. Journal of Economic Practices and Theories, 5(4), 22-25.

Lang, M., Lins, K.V., \& Maffett, M. (2012). Transparency, liquidity and valuation: international evidence on when transparency 
matters most. Journal of Accounting Research, 50(3), 729-774. doi:10.1111/j.1475679X.2012.00442.x.

Lyndenberg, S., Rogers, J., \& Wood, D. (2010). From Transparency to Performance. Industry - Based Sustainability Reporting on Key Issues. The Hauser Center for Nonprofit Organizations at Harvard University and Initiative for Responsible Investment. Retrieved June 5, 2015, from http://hausercenter.org/iri/ content/uploads2010/05/IRI_Transparency-toPerformance.pdf.

Maguire, M. (2011). The future of Corporate Social Responsibility Reporting. The Frederick S. Pardee Center for the study of the LongerRange Future. Boston University. Retrieved June 5, 2015, from http://www.bu.edu/pardee/ files/2011/01/PardeellB-019-Jan-2011.pdf.

Maignan, I. (2001). Consumers perceptions of corporate social responsibilities: a crosscultural comparison. Journal of Business Ethics, 30(1), 57-72. doi:10.1023/A:1006433928640.

Marais, M. (2012). CEO rhetorical strategies for corporate social responsibility (CSR). Society and Business Review, 7(3), 223-243. doi:10.1108/17465681211271314.

Margolis, J.D., Elfenbein, H.A., \& Walsh, J.P. (2007). Does it pay to be good... and does it matter? A meta-analysis of the relationship between corporate social and financial performance. Retrieved June 5, 2015, from: http://papers.ssrn.com/sol3/papers. cfm?abstract_id=1866371.

Marková, V., Lament, M., \& Wolak-Tuzimek, A. (2015). Reporting standards in socially responsible enterprises. Economic Annals-XXI, 9-10, 56-59.

Marková, V., Maráková, V., Hiadlovský, V., \& Wolak-Tuzimek, A. (2014). The concept of Corporate Social Responsibility in selected economic sectors. Radom: Wydawnictwo Naukowe Spatium.

Martinčik, D., \& Polívka, M. (2012). Contribution of Corporate Social Responsibility to the shareholder value: experimental perspective. E\&M Ekonomie a Management, 15(3), 108-124.

Pelsmacker de, P., Driesen, L., \& Rayp, G. (2005). Do consumers care about ethics? Willingness to pay for fair-trade coffee. The Journal of Consumer Affairs, 39(2), 363-385. doi:10.1111/j.1745-6606.2005.00019.X.

Plumlee, M., Brown, D., Hayes, R.M., \& Marshall, R.S. (2010). Voluntary environmental disclosure quality and firm value: further evidence (Working Paper). University of Utah and Portland State University. Retrieved June 5, 2015, from http://www2.business.umt.edu/ seminar/draft_Montana.pdf.

Pollach, I., Johansen, T.S., Nielsen, A.E., \& Thomsen, C. (2012). The integration of CSR into corporate communication in large European companies. Journal of Communication Management, 16(2), 204-216. doi:10.1108/13632541211217605.

Porter, M.E, \& Kramer, M.R. (2011). Creating Shared Value: How to Reinvent Capitalism and Unleash a Wave of Innovation and Growth. Harvard Business Review, 89.

Rodriguez, L.C., \& LeMaster, J. (2007). Voluntary Corporate Social Responsibility Disclosure: SEC CSR Seal of Approval. Business \& Society, 46(3), 370-384. doi:10.1177/0007650306297944.

Rourke, O. (2004). Opportunities and obstacles for corporate social responsibility in developing countries. University of California. Retrieved May 5, 2015, from http://nature. berkeley.edu/orourke/pdf/CSR-Reporting.pdf.

Sopková, E., \& Raškovská, K. (2012). The implementation of the concept of Corporate Social Responsibility in the area of income tax in The Slovak Republic. E\&M Ekonomie a Management, 15(2), 125-140.

Sutantoputra, A.W. (2009). Social disclosure rating system for assessing firms CSR reports. Corporate communication: An International Journal, 14(1), 34-48. doi:10.1108/13563280910931063.

Sweeney, L., \& Coughlan, J. (2008). Do different industries report Corporate Social Responsibility differently? An investigation through the lens of stakeholders theory. Journal of Marketing Communications, 14(2), 113-124. doi:10.1080/13527260701856657.

Schaltegger, S. (1997). Information Costs, Quality of Information and Stakeholder Involvement. Eco-Management and Auditing. 87-97. doi:10.1002/(SICI)1099-0925.

Tewari, R. (2011). Communicating Corporate Social Responsibility in Annual Reports: A Comparative Study of Indian Companies \& Multi-National Corporations. Journal of Management \& Public Policy, 2(2), 22-51. 
doc. Ing. Peter Krištofik, Ph.D.

Matej Bel University Faculty of Economics

Department of Finance and Accounting peter.kristofik@umb.sk doc. Ing. Hussam Musa, PhD. Matej Bel University Faculty of Economics

Department of Finance and Accounting hussam.musa@umb.sk

Marzanna Lament, Ph.D.

University of Technology and Humanities in Radom

Faculty of Economics

Department of Finance and Insurance m.lament@uthrad.pl 


\title{
THE REPORTING OF NON-FINANCIAL INFORMATION ANDTHE RATIONALE FOR ITS STANDARDISATION
}

\author{
Peter Krištofík, Marzanna Lament, Hussam Musa
}

CSR (Corporate Social Responsibility) is an important part of communication with stakeholders and a response to the need for non-financial reports. Regrettably, the rules of non-financial reporting are almost not regulated. CSR reports are drafted using a variety of principles and guidelines, which limits comparisons across enterprises, transparency and assessment of progress.

The reasons for reporting non-financial information cited in the specialist literature, and by enterprises preparing CSR reports are examined, and the benefits of standardising reports of nonfinancial information are determined.

The literature review and empirical research into the motivations for CSR reporting and the trends in reporting of non-financial information helped to verify the initial hypotheses:

1. Communication with stakeholders is the fundamental reason for reporting non-financial information. This is confirmed by the literature review, with most authors believing this is the prime reason for preparing CSR reports. Authors indicating other motivations still treat it as the fundamental cause which exists jointly with other motivations.

2. The need to standardise CSR reporting to ensure its transparency and clarity is noted by reporting organisations. This is proven by surveys of organisations drafting CSR reports approximately $80 \%$ of all reports follow the GRI guidelines. This means the reporting enterprises wish their reports to be clear, transparent and comparable and for their stakeholders to be able to fully satisfy their information requirements. This is also evidence of the care for good relations with stakeholders, who receive standardised data although this is not binding on enterprises. A growing tendency for CSR reporting to follow guidelines other than the GRI can be noted in the entire period under analysis. This will not necessarily be a single compulsory standard, yet a model report would need to be followed to assure transparency and comparability.

The Regulations of the Directive 2014/95/EU are a step forward since they will help to standardise rules of reporting non-financial information and will improve its transparency and utility.

Key Words: Corporate Social Responsibility, reporting, management.

JEL Classification: M14, M41.

DOI: 10.15240/tul/001/2016-2-011 